\title{
Dynamics of Social Protection in Context of Structural and Institutional Performances: A Disaggregate Analysis for Pakistan
}

\begin{abstract}
Ahmed Raza ul Mustafa ${ }^{1}$, Mohammed Nishat ${ }^{2}$
Abstract

This paper analyzes the dynamics of social protection expenditures in the context of structural and institutional characteristics across provinces in Pakistan. A rank and regression analysis is employed on a panel dataset for four provinces of Pakistan namely Khyber Pakhtunkhwa(KP), Balochistan, Sindh, and Punjab; over a period of 1988 to 2014. The analysis shows that KP gave more preference to education, health and, social security and welfare, and rank at the top in the respective social protection parameter. However, considering the structural and institutional features, KP shows a better performance in all social protection categories except social security and welfare. Punjab is in worst condition with respect to fiscal space generation, structural and institutional features in all social protection channels. Balochistan has better fiscal budget for subsidies and transfers but hasthe least structural and institutional features in utilizing these funds optimally. The Sindh province has the better structural and institutional performance for social protection provision but has comparatively low fiscal space for them. Theregression analysis results indicate that most of the structural and institutional features played a significant role in the determination of fiscal space for the concerned provinces. For Policy prospects, Sindh government needs to enhance the fiscal space for social protection purposes, whereas KP and Balochistan need to improve the required structural and institutional performance. In the case of Punjab, there is a need to enhance their fiscal space for social protection along with improved structural and institutional performances.
\end{abstract}

Key Words: Structural, Institutional, Governance, Social Protection, Disaggregate Analysis, Pakistan.

\section{JEL Classification: H55, I38, E62}

\section{Introduction}

Social protection is a source of socioeconomic development and an important

1 Incharge Chairman, Department of Economics, Shaheed Benazir Bhutto University (SBBU), Nawabshah. email:ahmedrazamustafa@sbbusba.edu.pk

2 Professor of Economics and Finance, Institute of Business Administration (IBA), Karachi.email: mnishat@iba. edu.pk

ARTICLE HISTORY
\begin{tabular}{ll}
22 May, 2018 Submission Received & 23 Nov, 2018 First Review \\
\hline 6 Feb, 2019 Second Review & 24 Feb, 2019 Third Review \\
\hline 4 Mar, 2019 Accepted
\end{tabular}


instrument used for crisis management. It ratifies a compact foundation for economic growth against spreading poverty and alleviating the effects of negative economic shocks. On basis of the social rights, provision of funds exists, and it encourages countries to meet universal standards of social protection. ${ }^{3}$ Social protection programsdiffer from province to province because they contain structural, institutional and culturaldynamicsin their respective societies. The initiatives for social protection programs are not only insufficientbutthe sustainability and continuity are too important to provide the social protection benefits to concerned societies. Further, the countries need to ensurethehigher levels of social protection by fulfilling their needs, preferences and the financial depth (World Bank, 2002; Sayeed, 2004).

In literature, the theoretical aspects of social protection provision and its long-term economic impacts are widely discussed (see Piece, 2012). Several empirical studies identify that astheprovision of better nutrition, education and health facilities through social protectionexpenditurecan make people a productive part of the workforce. For example, Atkinson (1995) and Subbarao et al. (1997) described that a major objective behind social protection is to alleviate chronic and transient poverty. Bonilla and Gruat (2003) described that social protection pursues people to carry out the risk for high return which moves toward the economic growth. Barrientos (2007), Handley (2009), and, Holmes and Jackson (2008) explained that social protection mechanism works under different financial channels, where the national government is one of them. Magdalena and Carly (2012) analyzed the social protection system in Finland and concluded that the legal and institutional framework play a vital role in confirming the benefits of individuals, as per their social rights. They supported the social protection programs and argued that it is a long lasting activity in the political cycle and should not be manipulated for political purposes. Francesca (2013) described that development of politically sustainable social contract is helpful to establish the permanent social protection system. Cardoso, Teixeira, Gurgel and Castro (2011) made a regionalcomparison for rural credit subsidy in Brazil and explained that efforts made by the government, enhance the welfare and economic growth. Moreover, it contributes to the society by diminishing regional disparities. Slater and Farrington (2009) studied the efficiency and effectiveness of social transfers. The mechanism of social transfers is to deliver resources to deserving people, whereas inefficiency of the system is a subject to least coverage of vulnerable people. Besley, Burgess and Rasul (2003) ranked developing and developed countries on the basis of social protection and welfare expendituresover the period 1972 to 1997. Barr (1994) sug-

3 According to the ILO, 'Social security refers to protection provided to the society through a series of government measures against social and economic status in different circumstances like illness, maternity, unemployment, injury and old age'. Social security is provided through public or collective provisions through private channels. It is not concerned with cash benefits but consider the basic needs (medical care, education, housing, nutrition, etc.). 
gested to enhancethe objectives of social protection by improving the consumption per capita, efficient redistribution of income, and political stability. Holzmann and Jorgensen (1999) claimed that public intervention is better to manage income risks that are assured by the social structure. These studies clearly identify the role and importance of social protection in both developing and developed economies. This study attempts to understand the dynamics and impact of initiatives taken by the government of Pakistan through constitutional amendments (2009-10) to facilitate the social protection expenditure at the disaggregated provincial level.

In Pakistan after the $18^{\text {th }}$ constitutional amendments and consensus on the $7^{\text {th }}$ National Finance Commission (NFC) award (2009-10), the domain of social protection allocation was shifted from federalgovernmentto provinces for a socio-economic prospect at inter and intra provincial level. Under $7^{\text {th }}$ NFC award transferred massive funds and liabilities from federal to provincial governments. This transfer of funds provides more fiscal space for provinces to play their role in addressing the interprovincial inequalities. After these constitutional amendments, most projects, related to social sectornamely; education, health, and social welfare were planned and implemented by the provincial governments. As a result, the federal government concentrated only on the budgetary allocations toward the development of infrastructure, energy,and invigilation to enhance performance in the social sector.

In 2014, the overall population was around 186 million where the per capita income was 1317 US dollar but the income inequality was increased. According to the IEG (2011), the top 20 percent of the individuals hold 42 percent of the total national income. It represents that 36 million people hold US $\$ 75.6$ billion which explains the per capita income of US \$2,100 which is twice the national average. Furthermore, 27 percent of the national income remains in the hands of 18 million people, who are in the top 10 percent of the population where the per capita income is the US \$2,700. According to Naveed and Nazim (2012), 58.7 million people live under the poverty line where 46 percent of them reside in rural areas and 18 percent live in the urban areas of Pakistan. In a provincial comparison, Balochistan is at the top rank where 52 percent of the total population lives below the poverty line. Sindh is the second, having 33 percent ratio. At the third place, the KP whose 32 percent of the population is living below the poverty line. Punjab is at the $4^{\text {th }}$ rank where 19 percent of the total population lives below the poverty line. ${ }^{4}$ These poverty trends in the provinces create a major interruption to socioeconomic development, and there is a need for social assistance in the form of subsidies and fund transfers, to overcome the poverty issues in Pakistan, like Benazir income support programs.

4 A survey report "Clustered Deprivation" is written by Sustainable Development Policy Institute (SDPI) under the financial and technical assistance by United Nation Development Program (UNDP). 
In Pakistan's prospect, the allocation of funds for social assistance programs was around Rs.179 billion in 2012, which is about 0.8 percent of the GDP, where 56 percent of the funds were used for cash transfer, social welfare programs, and food subsidies at the provincial level. The remaining 44 percentwere allocated against disaster and climate change. The overall expenditures for social protection purpose are very low, relative to average spending by the developing countries. ${ }^{5}$ According to the Nasim (2014), social safety nets in Pakistan provide the leasteffectiveness because they feed around 18percent of the poorest population in the country. This insufficient coverage has a strong association with persistent and high level of poverty and economic instability. Such circumstances create inadequate human capital that grows inequality, decrease aggregate demand and diminish the economic growth during the recession period.

Keeping in view the structure of economy, a rank,and regression analysis is made on the basis of social protection (education, health, social security and welfare, and, subsidies and transfers) expenditure, for the four provinces of Pakistan. The main objectives of the study are first, to analyzethe levels of financial resources allocated by the provincial government for social protection channels to meet the different welfare standards and second, to determine the impact of structuraland institutionalperformanceon the social protection at the provincial level where the structures features highlight the socioeconomic status and the institutional features talk about the policy changes for the economy at disaggregate level in Pakistan.Instead of optimizing the social protection expenditures, a comparative analysis through ranking approach is undertaken for social protection expenditures at the provincial level. The benchmark of performance level is the ability which maintains the structural and institutional indicators of the provinces. Attempts made to know the performance of provinces for social protection; different proxies used as a percentage of government tax revenue and total expenditure. This research highlights the structural and institutional parameters that play a vital role forthe provision of social protection supportive at province level.

The rest of the paper is organized as follows: Section 2 describes the review of the literature and theoretical framework. Section 3 outlines the proposed economic methodology and the econometric model. Empirical findings are explained in Section 4. The summary and concluding remarks are provided in Section 5.

\section{Literature Review}

A number of studies have been conducted, which focus on the objectives to analyses the role of government policies for the provision of social protection to reach the desired welfare level. How such policies are effective and working efficiently for the

5 Holzmann (2009) made the comparative analysis on the basis of the level of spending on social safety nets, covering 87 developing countries. Pakistan was getting her slot among the least one. 
fulfillment of the social protection objectives? The foremost techniques are followed for measurement of welfare with respect to social expenditures through the behavioral approach and the computable general equilibrium (CGE) model (Walle \& Neads, 1995; Selden \& Wasylenko, 1992).

The political backing and justification are effective by taking initiatives for social protection strategies, where the generation of fiscal space is subject to efficiency to get fruitful results. In the political scenario, the affordability depends on preferences made by the government. For outreach of social protection, the factors like public support for the policy, the degree of representing different groups and the social contracts, are important to have an equation between the political institutions and other stack holders. For social protection on the basis of enhancing marginal efficiencies and minimizing the external risks and frauds, the fiscal space is created.

Bonilla and Gruat (2003) described that social protection pursues people to carry out the risk for high return which moves toward the economic growth. Further, there is a development process to enhance human and social capital to have sustainable development in the economy by increasing economic productivity. Barrientos (2012), Handley (2009), and, Holmes and Jackson (2008) described that social protection mechanism works under different financial channels, where the national government is one of them. The affordability of social protection projects launched by the national government is important to sustain in the longrun, but it is not only the key, to fulfill the objectives of social protection. The outreach of these projects is not only important but feedback as well, which works as a toolkit for policy maker (Bastagli \& Soares, 2013). A pressure group is needed to raise the voice of people for social protection. Magdalena and Carly (2012) analyzed the social protection system in Finland by using the human rights approach. They concluded that the legal and institutional framework play a vital role in confirming the benefits of individuals, as per their social rights. The social protection program is also a long-lasting activity in the political cycle and should not be manipulated for political purposes.

Piece (2012) reported the theoretical aspects of social protection provision and its long-term economic impacts which found that maximizing human development objectives viatheprovision of better nutrition, education, and health facilities can make people a productive part of the workforce. Furthermore, it makes people potential members of society and such sustainability reduces poverty and inequality. Atkinson (1995) and Subbarao et al. (1997) described that the major objective behind the social protection is to alleviate chronic and transient poverty. They determine that the private social protection strategies like community-based organizations are helping to alleviate adverse outcomes of poverty. On the other hand,the provision of good health and education service, fund transfers like food subsidies and social insurance 
by public intervention is too effective to counter the poverty.

Francesca (2013) described that development of politically sustainable social contract is helpful to establish the permanent social protection system. Essential public choice and priorities need to be made for utilization of scarce resources. The political performance is to locate those who deserve to impart help at his/her end. This can improve welfare standards of developing countries, where weak social protection strategies attribute in the absence of social contracts ${ }^{6}$. Cardoso et al. (2011) made a regional comparison for rural credit subsidy in Brazil and explained that efforts made by the government, not only enhancedthe welfare and economic growth, but it also contributed to the society through minimizing the regional disparities.

Dercon (2011) tried to check the social protection structure, its efficiency and the role of such social protection parameters in economic growth. They found that social protection in the form of cash transfers might not be an incentive for economic growth because in terms of cash transfer the demand will increase without increasing production and allocative efficiency. In other words, cash transfer may create demand-pull inflation in the economy. Therefore, there is a need to generate different income opportunities for individuals, which will help them to enhance their per capita income by improving economic activities in the concerned economies. Further, there is a need to transfer cash to those people who are below the poverty line and have no ability to face macroeconomic shocks. Ravallion (2003) and Dercon (2005) disclosed that market failure can only be adjusted by enhancing economic efficiency. It allows households to utilize their resources in an efficient way, to have a substantial level of economic growth.

Slater and Farrington (2009) studied the efficiency and effectiveness of social transfers. The mechanism of social transfers is to deliver resources to deserving people, whereas inefficiency of the system is a subject to least coverage of vulnerable people. There are loopholes which are responsible for the inefficiency like political intervention in decision making that polluted the fiscal budget allocation. Besley et al. (2003) targeted the developing and developed countries by using social protection and welfare expenditures over the period 1972 to 1997. They ranked countries on the basis of social protection and welfare expenditures. Thereafter they checked the impact of structural and institutional factors on social protection, as well as, the welfare parameters. They concluded that most countries allocate their funds for social protection but, get more or less fruitless results with respect to welfare due to weak structural and institutional performance indicators.

In an inclusive way, Barr (1994) enhance the objectives of social protection by

6 See Barrientos (2012) 
improving the consumption per capita, efficient redistribution of income, to have political stability. Holzmann and Jorgensen (1999) claimed that public intervention is better to manage income risks that are assured by the social structure. Barrientos and Hulme (2009) tested the future of social protection for the developing world. They argued that the role of national governments in framing and directing the policies are important, and highlighted the need for a political structure that can be favorable, both for the initiative of social protection programs and its sustainability.

In conclusion, there is a general consensusinempiricalliterature that justifies the effective role of social protection expenditures in the social sector, subsidies, and welfare programs in various economies through needed structural changes and effective implementation of these policies. Moreover, the political preferences at the provincial level strengthen the outreach of social protection, through required coordination and effective implementation to achieve the objectives of social protection in the concerned provinces in Pakistan. This study establishes the link and assesses the effectiveness of expenditures on various social sectors after $18^{\text {th }}$ amendment of 2009-10. The same will provide guidelines for policymakers for the uplifting of target societies in Pakistan.

\section{Econometric Methodologyand Data Description}

In order to make the economic and econometric model, rank and regression analysis are made, respectively.

\subsection{Social protection rank analysis}

Given the level of social protection expenditures, structural and institutional features; three ranks are constructed based expenditure on health, education, and social security and welfare. The education expenditures are taken as a proxy for social protection that measures the government spending for the provision of educational services to generate human capital and increase the literacy rate of relevant societies. Such proxies cover the whole expenditures which are made by the provincial governments. The health expenditures describe the provision of health services to the societies that contain the cost of research and developmentas well as, the medical facilities. The social security and welfareis a social protection channel that measures the level of spending by the government for social security to increase the welfare of the societies. Similarly, subsidies and transfers is a social protection instrument which is useful to protect deserving people of the societies. In the form of such support, it is helpful to pull people from chronic poverty. All proxies are taken as percent of total tax revenue collection by the provincial governments. 


\subsubsection{Rank-1 based on fiscal constraint and social protection}

A cross-province panel data set which covers the period 1988 to 2014 is generated to define the social protection expenditures of type $r$ for the province $s$ at time $t$, as a percentage share of the total government tax revenue, denoted as. By averaging the data over time period, Rank-1 is constructed, which shows the order of provinces according to the time average spending on social protection. Hence, Rank-1 defines the fiscal space generated by provinces for social protection purpose. The highest provincial rank is represented by the highest level of spending for social protection, averaged over the given time period. Rank-1 shows the time averaged level of social protection expenditure of type $r$ for province $s$, asa percent share oftotal tax revenue collection by the provincial governments?

\subsubsection{Rank-2 based on structural features and social protection}

In order to construct Rank-2,a panel least square method is used,

$$
S P_{r s t}=\eta_{r}+\sum_{p=1}^{4} \eta_{r p} S F_{p s t}+u_{r s t} \text { for } r=1,2,3,4
$$

where, $\mathrm{SP}_{\text {rst }}$ describes the social protection expenditures of type $r$ for province $s$ at time t. $\eta$ is a vector of constant intercepts. The $\mathrm{SF}_{\mathrm{pst}}$ is a vector of structural features of province $s$, at time $t$. More specifically,

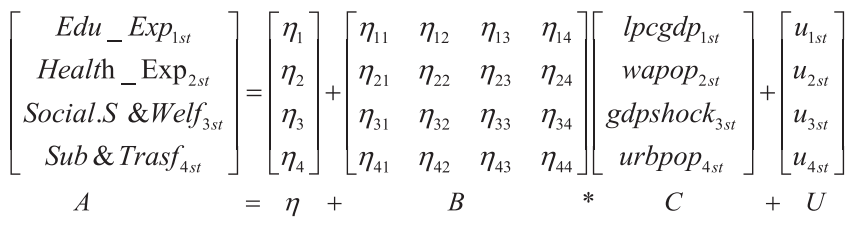

where $A$ is a matrix of social protection expenditures, $\eta$ shows the matrix of constant intercepts, B explains the coefficient matrix of structural features, $\mathrm{C}$ matrix consists of the structural features of the provinces and $U$ presents the matrix of residual series got from system of equations (2). In matrix C, $\operatorname{lpcgd}_{\mathrm{st}}$ describes the logarithmic form of per capita GDP that represent the diminishing marginal benefits by increasing personal income, wapop $_{\text {st }}$ elucidates the working age population percentage of total population, as the labor force. The gdpshock $_{\text {st }}$ variable explains the per capita GDP shock i.e., how far a province is from its long run sustainable income level in a certain year, because such cyclical components could also be correlated with social protection expenditures. The urbpop $_{\mathrm{st}}$ measures the share of urban population, who can easily transmit their voice to the government to get their social rights than the rural population. There after analyzing the system of equations (2) a residual series

7 For robustness check, proxy like social protection indicators percentage of total government expenditures is also used 
$\mathrm{u}_{\mathrm{rst}}$ is obtained that describes the variation in social protection expenditure, under or over explained by structural features of the provinces. Such residual values describe the potential of a province to spend for social protection purposes and needed financial resources needed for societies protection.

To develop Rank-2, an ordering of time average residual values within the province $\mathrm{u}_{\mathrm{rs}}$ is made. Such time average summary statistics is valuable to make comparative analysis among the provinces. TheRank-2criteria depends on under/over the explained part of social protection expenditures where structural features $\mathrm{SF}_{\mathrm{pst}}$ are controlled by provinces. The time averaged residuals might be positive or negative, depending on the structural features of the province. The positive/negative values imply that, on an average, province $s$ spends high/low on social protection type $r$, at a given structural parameters ${ }^{8}$. Rank-2 shows the time averaged residual values $\mathrm{u}_{\mathrm{rs}}$ that shows the under or over explained part of structural features of the provinces. Diminishing Rank-2, the values indicate that a relevant province spend less, as expected by the structural features of that province and vice versa.

\subsubsection{Rank-3 based on institutional features and social protection}

This criterion measures how much the unexplained part of social protection expenditures for a province $s$ can be explained by institutional features, by running a pool regression estimates. More specifically by regressing the institutional quality measures on the pool residual series are as given below

$$
u_{r s t}=\rho_{r}+\sum_{q=1}^{4} \rho_{r q} I F_{q s t}+v_{r s t} \text { for } r=1,2,3,4
$$

where $\mathrm{u}_{\mathrm{rst}}$ represents the residual series obtained by incorporating the structural features of provinces in regression function (2). The incorporate the institutional features of type $r$, for province $s$ at time $t$. In a more elaborated way,

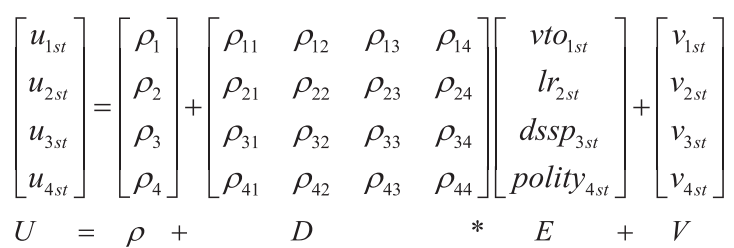

Where $U$ is a column vector of error terms calculated from a system of equations (2), shows the column vector of constant intercepts, D matrix explains the coefficients of institutional features, E matrix defines the institutional features of provinces and $\mathrm{V}$ represents the matrix of residual series. From the matrix E, the $\mathrm{vto}_{\mathrm{st}}$ stands for voter turnout that describes the percentage share of entitled voter in provinces, who

8 See Besley et al.(2003) 
actively casted their vote in the previous elections, the period under study. It measures the political participation and spirit of people to elect politicians. The provincial literacy rate is denoted by $\operatorname{lr}_{\text {st }}$ which is used to know how well the people understand about the government policies. The $\mathrm{dssp}_{\mathrm{st}}$ defines the deviation of social spending from its own provincial mean. It shows as to how the concerned governments set their priorities to spend for social purpose during different time periods. In the last, polity $_{\mathrm{st}}$ represents the political structure like democratic and autocratic trends in the economy. Such indicators might be functional for the institutional performance (see Besley et al., 2003).

Rank-3 derived by keeping in mind the institutional features of the provinces. Lowering this rank infers that a province which is not spending as much on social protection, as expected by the controlling the institutional features of that province. From the system of equations (4) the average residual series $\mathrm{v}_{\mathrm{rs}}$ is developed to construct Rank-3, where the values of this series might be positive or negative. When the sign is positive, it predicts that a province is expected to spend more on social protection and vice versa for the negative sign. Ordering provinces on the basis of averaged residual $\mathrm{v}_{\mathrm{rs}}$ values is denoted by Rank-3.

In order to check the capacity and ability of a province to spend on social protection practices, a comparison amongRank-1, Rank-2and Rank-3 is made. If a province holds a lower value in Rank-1 but the higher value in Rank-2, it means that the province has the ability to spend more on social protection, due to its structural features and vice versa. If it retains high value in Rank-3 as well, it ensures that its institutional potency is stronger to allocate the given resources efficiently, for social protection.

\subsection{Data description}

The study made a comparative analysis of the four provinces (Punjab, Sindh, KP, and Balochistan) in Pakistan. Thedata set consist of social protection, structural and institutional indicators, is collected from the Pakistan Statistics Year Book (1989 to 2016), Bengali and Sadaqat (2006) ${ }^{9}$,Pakistan Labor Force Survey (1989-2014), Gallup (2013) Pakistan, INSCR (2014) and annual reports published by respective department of provincial governments ${ }^{10}$,thedetails are given in Table 1.

\section{Discussion of Empirical Results}

This section provides detail on the empirical findings of the social protection rank analysis as well as the regression analysis as given below.

9 Data is extended for the period (2001 - 2014).

10 Punjab Development Statistics, Development Statistics of Sindh, NWFP Development Statistics, and Development Statistics of Balochistan. 
Table 1: Variables and Data Sources

\begin{tabular}{|c|c|c|c|}
\hline Type & Variable & Explanation & Data Source \\
\hline \multirow{4}{*}{ 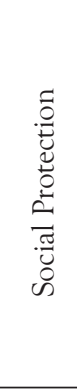 } & Edu_Exp & $\begin{array}{c}\text { Education Expenditures \% Tax Revenueand } \\
\text { Total Govt. Exp. separately }\end{array}$ & $\begin{array}{c}\text { Pakistan Statistics Year } \\
\text { Book (1989-2016) }\end{array}$ \\
\hline & Health_Exp & $\begin{array}{l}\text { Health Expenditures \% Tax Revenueand } \\
\text { Total Govt. Exp. separately }\end{array}$ & $/ /$ \\
\hline & Social S.\& Welfare & $\begin{array}{l}\text { Social Security \& Welfare Expenditures \% } \\
\text { Tax Revenueand Total Govt. Exp.separately }\end{array}$ & $/ /$ \\
\hline & Sub\&Trasf & $\begin{array}{c}\text { Subsidies \& transfers \% Tax Revenueand } \\
\text { Total Govt. Exp.separately }\end{array}$ & // \\
\hline \multirow{4}{*}{ 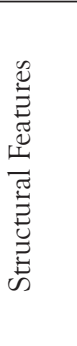 } & $\operatorname{lpcgdp} p_{\text {st }}$ & logarithmic form of per capita GDP & $\begin{array}{l}\text { Bengali and Sadaqat } \\
\text { (2006) }\end{array}$ \\
\hline & wapop $_{\text {st }}$ & $\begin{array}{l}\text { working age population as a proportion of } \\
\text { the total population }\end{array}$ & $\begin{array}{l}\text { Pakistan Labor Force } \\
\text { Survey (1989-2014) }\end{array}$ \\
\hline & gdpshock $_{\text {st }}$ & Per capita GDP shock & Author Estimated $_{1}$ \\
\hline & urbpop $_{\mathrm{st}}$ & urban population over the total population & $\begin{array}{l}\text { Pakistan Labor Force } \\
\text { Survey }(1989-2014)\end{array}$ \\
\hline \multirow{4}{*}{ 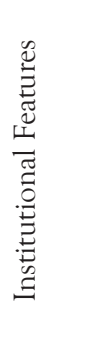 } & vto $_{\text {st }}$ & Voter turn out & $\begin{array}{l}\text { Gallup (2013) Paki- } \\
\operatorname{stan}_{12}\end{array}$ \\
\hline & $\operatorname{lr}_{\mathrm{st}}$ & Literacy rate & $\begin{array}{l}\text { Provincial Develop- } \\
\text { ment Annual Reports }\end{array}$ \\
\hline & $\mathrm{dssp}_{\mathrm{st}}$ & Deviation in per capita social spending & $\begin{array}{c}\text { Pakistan Statistics Year } \\
\text { Book (1988-2016) }\end{array}$ \\
\hline & polity $_{\text {st }}$ & Political pattern (Democratic or Autocratic) & INSCR (2014) \\
\hline
\end{tabular}

Source: Author's estimation from various sources

\subsection{Social protection rank analysis}

Comparing the social protection expenditures, each province has its own breakdown for education, health, social security and welfare, and, subsidies and transfers. The comparison among the provinces shown in Figure 1 highlights that KP spends the highest on all social protection channels except subsidies and transfers. Conversely, Balochistanhas the lowest ranked provincein fiscal space generation for concerned social protection programs except forsubsidies and transfers. Punjab and Sindh are below the KP for creating a healthy environment for social protection. Furthermore, as shown in Figure 1 each category of social protection is able to disclose the ranking of each province in the respective segment of social protection. For example, in education expenditure, $\mathrm{KP}$ is spending (19.17\%) more than other provinces, whereas Balochistan spends (12.17\%), lesser compared to other provinces. In the case of health expenditure, 
KP stands the highest with 5.53percent of fiscal allocation, whereas Balochistan holds the least position in this category. In social security and welfare, all other provinces spend a minute portion of tax revenues where the $\mathrm{KP}$ is spending 1.58 percent and the Balochistan, just 0.38percent of their respective fiscal allocations. As for as, the subsidies and transfers are concerned, the Balochistan leads in this category with 5.13 percent. Astonishingly the Punjab, just spend 2.40percent of its tax revenue; which is the least than other provinces.

In the rank analysis, considering the level of social protection expenditures, structural and institutional features of provinces, three ranks are constructed, as shown in Table 2.Results indicate that KP and Balochistan capture the extreme positions

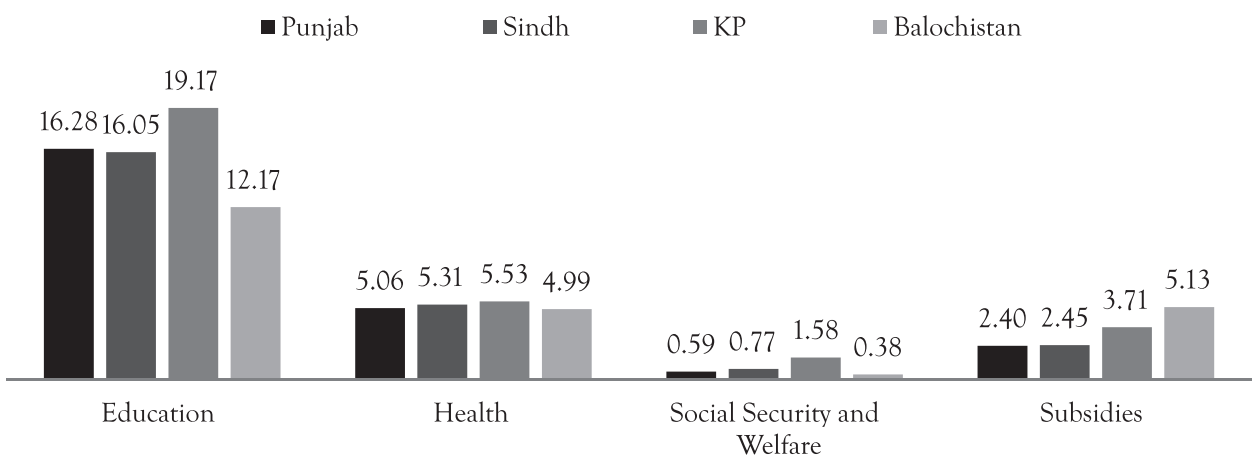

Figure 1: Social Protection Expenditures \% of Tax Revenue Source: Author's estimation

(highest and lowest, respectively) in the provincial comparison for spending on education. Both provinces maintain their position in Rank-2 and Rank-3 for structural and institutional indicators. On the other hand, Punjab maintains the second position in Rank-1 but it loses its position in Rank-2 and Rank-3 which indicates that it has a respectable spending on education but low structural and institutional features as compared to other provinces. Sindh is better in Rank-2 and Rank-3and shows a reasonable structural and institutional feature to utilize the balances for education purposes even though owning a low fiscal space for it.

Taking into account the health expenditures, KP holds the highest position in Rank-1, Balochistan holds the lowest rank because of low fiscal space for health. In the rank comparison, Balochistan is in the worst condition as per the structural and institutional features. KPutilize its resources for health in an efficient way as per their structural and institutional features. Sindh and Punjab are securing the second and third position in Rank-1 respectively. It is notable thatSindh has better structural and institutional features than Punjab for the health sector. 
In the provision of social security and welfare expenditure, KPcaptures the highest fiscal space but shows a least structural performance as compared to institutional one, in utilizing these resources. Sindh has a second position for creating the fiscal space for

Table 2: Rank Analysis in Context of Social Protection Provision

\begin{tabular}{|c|c|c|c|}
\hline Edu_Exp & Rank-1 & Rank-2 & Rank-3 \\
\hline KP & 1 & 2 & 2 \\
\hline Punjab & 2 & 3 & 3 \\
\hline Sindh & 3 & 1 & 1 \\
\hline Balochistan & 4 & 4 & 4 \\
\hline
\end{tabular}

\begin{tabular}{|c|c|c|c|}
\hline Health_Exp & Rank-1 & Rank-2 & Rank-3 \\
\hline KP & 1 & 1 & 2 \\
\hline Sindh & 2 & 2 & 1 \\
\hline Punjab & 3 & 3 & 3 \\
\hline Balochistan & 4 & 4 & 4 \\
\hline
\end{tabular}

\begin{tabular}{|c|c|c|c|}
\hline Health_Exp & Rank-1 & Rank-2 & Rank-3 \\
\hline KP & 1 & 1 & 2 \\
\hline Sindh & 2 & 2 & 1 \\
\hline Punjab & 3 & 3 & 3 \\
\hline Balochistan & 4 & 4 & 4 \\
\hline
\end{tabular}

\begin{tabular}{|c|c|c|c|}
\hline Sub \& Trasf. & Rank-1 & Rank-2 & Rank-3 \\
\hline Balochistan & 1 & 3 & 3 \\
\hline KP & 2 & 1 & 2 \\
\hline Sindh & 3 & 2 & 1 \\
\hline Punjab & 4 & 4 & 4 \\
\hline
\end{tabular}

Source: Author's estimation

social security and welfare but there is a fund utilization problem due to least position in Rank-2 and Rank-3. Punjab has the third position in Rank1due to least preference for social security and welfareandfurther loses its position in Rank-3that is a sign of very poor institutional performance. Balochistan has the lowest position in Rank-1 but stands at a top position in Rank-2 and Rank-3. It reveals that Balochistan has the capacity to utilize the funds for social security and welfare but has a low fiscal budget.

In subsidies and transfers, Balochistan secures a top position in Rank-1, due to allocating a maximum fiscal budget but loses its position in Rank-2 and Rank-3due to worst structural and institutional performance. Punjab holds the lowest position in all three ranks which explains that there is not only the lowest fiscal budget allocated by Punjab government but also have the insufficientstructural and institutional performance for the provision of subsidies and transfers. Sindh securesthe third position in Rank-1and gradually improved its position in Rank-2 and Rank-3 that is a sign of betterment of structural and institutional performance for the provision of subsidies and transfers.

For the robustness check, the same analysis is repeated by using the proxy for social protection expenditures as a percentage of total government expenditure ${ }^{11}$. More or

11 Appendix II represent to the results by using the social protection proxies as percentage of government total expenditures. 
lessthesame results are attained that indicates no principal change exist with respect to previous results. It concludes thatthe standing position of the provinces does not change and endorse the perfection of social protection rank analysis.

\subsection{Regression analysis}

\subsubsection{Social Protection and Structural Features}

A system of equations (2) is used to construct Rank-2 where the results are shown in Table 3. Such results are effective for policy making at provincial level about structural features that play their role for determination of fiscal space for social protection channels. It is observed that provincial per capita GDP is significant and negative in relation to each social protection indicators with respect to the tax revenue. It advocates that as thelevel of per capita GDP goes down, the provincial governments allocate their funds for social protection purpose, except the social security and welfare, because of increasing income inequalities (Perotti, 1996; Arjona,Ladaique\& Pearson, 2002). The proportion of the working age population is negative in relation to social protection expenditures. It predicts that increasing the proportion of working-age population is subject to reduce the level of dependency and need less social protection benefits for the remaining population (Besley et al., 2003).

Per capita GDP shock variables explain the positive and significant relationship with education and subsidies and transfers. Such association illustrates that shocks in the GDP are pro-cyclic ${ }^{12}$ for determination of the level of social spending. Such positive shocks generate the potential for the government to create more fiscal space for social protection purposes. Urban population proportion plays a significant and positive role for the determination of fiscal space for social protection channels. It suggests that the urban poor can easily transmit their voice to the government to get their social rights than the rural population. Hence, increasing the urban population can be a driving force for the creation of fiscal space for social protection purpose by the government.

\subsubsection{Social Protection and Institutional Features}

The regression results are presented in Table 4 incorporate institutional features of provinces in the system of equations (4) where the voter turnout shows the positive but insignificant impact on spending for social protection. The increasing voters' turnout ratio represents people to elect politicians as per their own likeness/interest and they make efforts to fulfill their social rights (James \&Yackovlev, 2000). The positive sign of voters' turnover is advocating the theory but havethe least empirical

12 Existence of the positive shocks in GDP will move toward the more fiscal space for social protection purposes. Such fiscal space will enhance the social spending in the concerned societies. 
Table 3: Regression Analysis for Structural Features and Social Protection

\begin{tabular}{|c|c|c|c|c|}
\hline $\begin{array}{l}\text { Dependent } \\
\text { Variable }\end{array}$ & Edu_Exp & Health_Exp & Social S \&Welf & Sub \& Trasf \\
\hline Variable & $\begin{array}{l}\text { Coefficient } \\
\text { (t-Statistic) }\end{array}$ & $\begin{array}{l}\text { Coefficient } \\
\text { (t-Statistic) }\end{array}$ & $\begin{array}{l}\text { Coefficient } \\
\text { (t-Statistic) }\end{array}$ & $\begin{array}{l}\text { Coefficient } \\
\text { (t-Statistic) }\end{array}$ \\
\hline \multirow[t]{2}{*}{ C } & 3.016 & 0.355 & -0.368 & 0.745 \\
\hline & $(4.741)^{*}$ & $(2.623)^{*}$ & $(-2.717)^{*}$ & $(4.261)^{*}$ \\
\hline \multirow[t]{2}{*}{ LPCGDP } & -0.826 & -0.087 & 0.115 & -0.197 \\
\hline & $(-4.411)^{*}$ & $(-2.171)^{*}$ & $(2.875)^{*}$ & $(-3.825)^{*}$ \\
\hline \multirow[t]{2}{*}{ WAPOP } & 0.024 & -0.012 & -0.062 & -0.076 \\
\hline & $(0.113)$ & $(-0.262)$ & $(-1.368)$ & $(-1.301)$ \\
\hline \multirow[t]{2}{*}{ GDPSHOCK } & 0.254 & 0.010 & 0.031 & -0.017 \\
\hline & $(4.659)^{*}$ & $(0.842)$ & $(2.591)^{*}$ & $(-1.120)$ \\
\hline \multirow[t]{2}{*}{ URBPOP } & 0.005 & 0.001 & -0.001 & 0.001 \\
\hline & $(3.277)^{*}$ & $(1.630)$ & $(-2.556)^{*}$ & $(2.251)^{*}$ \\
\hline R-squared & 0.294 & 0.058 & 0.136 & 0.266 \\
\hline $\begin{array}{l}\text { Adjusted } \\
\text { R-squared }\end{array}$ & 0.267 & 0.021 & 0.103 & 0.238 \\
\hline F-statistic & $10.738^{*}$ & 1.574 & $4.057^{*}$ & $9.356^{*}$ \\
\hline Prob(F-statistic) & 0.000 & 0.187 & 0.004 & 0.001 \\
\hline
\end{tabular}

Source: Author's estimation, Note: Social Security and Welfare (SSEC), Subsidies and Transfers (SUB), * and ${ }^{* *}$ significant value at $5 \%$ and $10 \%$ level of significance.

support for the social protection provision.

Theoretically, a direct relationship exists between literacy rate and quality of governance policiesas well as the people awareness to ensure effective social protection provision, however, the results are contrary and statistically insignificant. Our results are consistent with the earlier study and conclude that the adult literacy rate is not effective for the improvement of the institutional features (Javaid, Iftikhar, \& Ahmed 2017). Such ineffectiveness of the quality of education due to a lack of perceptiveness, cannot improve the governance features to promote social protection parameters.

The negativeandsignificant relationship of deviation in social spending with social protection channels describe the existence of inefficient and insufficient allocation of resources rather than the need of relevant people. It also reveals that the priorities set by the concerned provincial governments are not effective for the social protection provision to fulfill the need of the deserving people. The polity index plays a significant 
Table 4: Regression Analysis for Institutional FeaturesandSocialProtection

\begin{tabular}{|c|c|c|c|c|}
\hline $\begin{array}{c}\text { Dependent } \\
\text { Variable }\end{array}$ & Edu_Exp_R & Health_Exp_R & $\begin{array}{c}\text { Social S } \\
\& \text { Welf_R }\end{array}$ & Sub \&Trasf_R \\
\hline Variable & $\begin{array}{l}\text { Coefficient } \\
\text { (t-Statistic) }\end{array}$ & $\begin{array}{l}\text { Coefficient } \\
\text { (t-Statistic) }\end{array}$ & $\begin{array}{l}\text { Coefficient } \\
\text { (t-Statistic) }\end{array}$ & $\begin{array}{l}\text { Coefficient } \\
\text { (t-Statistic) }\end{array}$ \\
\hline \multirow[t]{2}{*}{$\mathrm{C}$} & 0.051 & 0.003 & -0.006 & 0.013 \\
\hline & $(1.344)$ & $(0.372)$ & $(-0.662)$ & $(1.184)$ \\
\hline \multirow[t]{2}{*}{ VTO } & 0.001 & 0.001 & 0.002 & -0.001 \\
\hline & $(0.617)$ & $(1.072)$ & $(0.797)$ & $(-0.507)$ \\
\hline \multirow[t]{2}{*}{ LR } & -0.002 & -0.001 & -0.001 & -0.002 \\
\hline & $(-2.229)^{*}$ & $(-1.898)^{* *}$ & $(-0.228)$ & $(-0.229)$ \\
\hline \multirow[t]{2}{*}{ DSSP } & -0.706 & -0.107 & -0.037 & -0.315 \\
\hline & $(-0.924)$ & $(-0.667)$ & $(-0.203)$ & $(-1.387)$ \\
\hline \multirow[t]{2}{*}{ POLITY } & 0.004 & 0.002 & -0.011 & -0.001 \\
\hline & $(3.016)^{*}$ & $(3.632)^{*}$ & $(-0.192)$ & $(-2.622)^{*}$ \\
\hline R-squared & 0.188 & 0.201 & 0.008 & 0.081 \\
\hline $\begin{array}{l}\text { Adjusted } \\
\text { R-squared }\end{array}$ & 0.155 & 0.168 & -0.032 & 0.044 \\
\hline F-statistic & $5.674^{*}$ & $6.162^{*}$ & 0.201 & $2.168^{* *}$ \\
\hline Prob(F-statistic) & 0.001 & 0.001 & 0.937 & 0.078 \\
\hline
\end{tabular}

Source: Author's estimation, Note: (_R) residual series get from the system of equations (4), *and ** significant value at $5 \%$ and $10 \%$ level of significance respectively.

and positive role for determination of social protection expenditures and predicts that democratic period provides a favorable environment to generate fiscal space for education and health sector.Also, the autocratic era is too effective for the subsidy provision in the concerned provinces in Pakistan.

\section{Summary and Concluding Remarks}

This research study explores the dynamics of social protection expenditures in context to the structural and institutional performance of provinces in Pakistan. In order to manage this task, a panel data set is used by considering four provinces for the period 1988 to 2014. Most of the results are indicative and consistent with empirical studies in developing economies highlighted in the literature.A rank analysis is made, subject to the level of social protection expenditures, structural and institutional features. KPgovernment gives more preference to education, health and, social security and welfare. On the other hand, the Balochistangovernment prefers to spend more 
on subsidies and transfers as compared to the other social protection channels. On the basis of these preferences, such provinces rank at the top in their respective social protection parameter. Furthermore, by considering the structural and institutional features of the provinces, it is concluded that KP showed better performance in all social protection category except social security and welfare, whereas, Punjab is in worst condition with respect to fiscal space generation, structural and institutional features in all social protection channels. Balochistan has a big tendency to allocate funds forsubsidies and transfers but showed the least structural and institutional features in utilizing these funds optimally. Sindh has the better structural and institutional performance for social protection provision but comparatively, have low fiscal space for them.

The regression analysis results indicate thatthe structural features like per capita GDP, urban population proportion and per capita GDP shock have shown their significance for the fiscal space generation in concerned provinces. As per the institutional performance, literacy rate and political stability supported well for the respectable fiscal space generation in all provinces of Pakistan. By reviewing the economics of social protection at provincial level there is some policy discourse as Sindh government has a need to enhance the fiscal budget for social protection purposes and other provincial governments have a need to improve their structural and institutional performances. As for as the Punjab government is concerned, it needs to increase the fiscal budget and look up the structural and institutional performance.TheKP needs to increase the fiscal space for subsidies and transfers and have a look at structural and institutional performance for the provision of social security and welfare.In conclusion, these findings may be useful for planning purposes at the provincial level in Pakistan.

\section{References}

Arjona, R., Ladaique, M., \& Pearson, M. (2002).Social protection and growth. OECD Economic Studies,35(7), 7-45. http://dx.doi.org/10.1787/eco_studies-v2002-art8-en

Atkinson, A. B. (1995). On targeting social security: Theory and western experience with family benefits. In D. van de Walle. \& K. Nead (eds.), Public spending and the poor: Theory and Evidence. (pp. 25-65). Baltimore: The Johns Hopkins University Press.

Barr, N. (1994). On the design of social safety nets. ESP Discussion Paper Series 65. Washington, D.C. World Bank: Education and Social Policy Department.

Barrientos, A. (2007). Financing social protection. Working Paper No. 05. Brooks World Poverty Institute. Available at SSRN: http://dx.doi.org/10.2139/ssrn.1204582

Barrientos, A. (2012). Social transfers and growth. What do we know? What do we need to find out? World Development, 40(1), 11-20. 
Barrientos, A., \& Hulme, D. (2009). Social protection for the poor and poorest in developing countries: Reflections on a quiet revolution. Oxford Development Studies, 37(4), 439-456.

Bastagli, F., \& Soares, F. V. (2013). The future of social protection in Brazil: Challenges and possible responses. In J. Midgley \& D. Piachaud (eds.) Social protection, economic growth andsocial change. (pp. 184-210). Edward Elgar Publishing, UK.

Bengali, K., \& Sadaqat, M. (2006). Provincial accounts of Pakistan: Methodology and estimates (1973-2000). SPDC Working Paper No. 5, Social Policy and Development Centre, Karachi.

Besley, T., Burgess, R., \& Rasul, I., (2003). Benchmarking government provision of social safety nets. Social Protection Discussion Paper Series, No. 0315, The World Bank.

Bonilla, G., \&Gruat, J. V. (2003). Social protection: A life cycle continuum investment for social justice. Poverty Reduction and Sustainable Development, Version 1.0, Geneva: Social Protection Sector, ILO, www. ilo.org/public/English/socialprotection.

Cardoso, D. F., Teixeira, E. C., Gurgel, A. C., \& Castro E. R. (2011). Effects of the rural credit interest rate equalization policy on Brazilian regions economic growth Paper presented at the 14th Annual Conference on Global Economic Analysis, Venice, Italy. Retrieved from https://www.gtap.agecon.purdue.edu/ resources/download/5372.pdf

Dercon, S. (2005). Insurance against poverty. Oxford University Press.

Dercon, S. (2011). Social protection, efficiency, and growth. CSAE working Paper WPS/2011-17, Center for the Study of African Economics. University of Oxford.

Francesca, B. (2013). Feasibility of social protection schemes in developing countries. Policy Department, Directorate-General for External Policies of the Union, ISBN: 978-92-823-4121-6 Retrieved from http://www.europarl.europa.eu/activities/committees/studies.do?language=EN

Gallup, (2013).The view tide of voter turn-out. Report on Voter Turn-out in Pakistan's National Election: 2013, Pakistan.

Handley, G. (2009). Fiscal space for strengthened social protection. Report commissioned by UNICEF West and Central Africa Office. London: ODI.

Holmes, R.,\& Jackson, A., (2008). Cash transfers in sierra leone: Are they appropriate, affordable or feasible? Project No 8, London: Overseas Development Institute. Available at www.odi.org.uk/plag/projects/ cash_transfers.html.

Holzmann, R., \& Jorgensen, S. (1999). Social protection as social risk management: Conceptual underpinnings for the social protection sector. Social Protection Discussion Paper, Series: no. SP 9904, Washington, D.C.: The World Bank.

Holzmann, R., (ed.) (2009). Social protection and labor at the world bank, 2000-08. Washington, DC: The World Bank. 
IEG (Independent Evaluation Group). 2011. Social Safety Nets: An Evaluation of World Bank Support, 2000-2010. Washington, DC: Independent Evaluation Group, the World Bank Group.

INSCR, (2014). Polity IV annual time series 1800-2014.Vienna, VA 22180 USA: Center for Systemic Peace.

James M., \&Yackovlev, I. (2000). Political and economic determinants of changes in government spending on social protection programs. Latin America and Caribbean Studies, Background Paper, Washington, D. C: World Bank.

Javaid, M. N., Iftikhar, M. N. \& Ahmed, G., (2017). What drives the quality of institutions in Asian economies? Journal of South Asian Studies, 5(3), 127-139.

Magdalena, S., \& Carly, N. (2012). The human rights approach to social protection. Ministry of Foreign Affairs of Finland, Report available at SSRN: https://ssrn.com/abstract=2114384

Nasim, A. (2014). Fiscal space for social protection in Pakistan. Policy Paper No. 01-14, Lahore: Institute for Development and Economic Alternatives (IDEAS).

Naveed A., \& Nazim, A. (2012). Clustered deprivation: District profile of poverty in Pakistan. Islamabad, Pakistan: Sustainable Development Policy Institute (SDPI).

Nead, K., \& Van de Walle, D. (Eds.). (1995). Public Spending and the poor: Theory and Evidence. Johns Hopkins University Press.

Perotti, R. (1996). Growth, income distribution, and democracy: What the data say? Journal of Economic Growth, 1(2), 149-87.

Piece, T. T., (2012). Social Protection: A Development Priority in the Post- 2015 UN Development Agenda. New York: United Nations System Task Team on the Post-2015 UN Development Agenda.

Ravallion, M. (2003). Targeted transfers in poor countries: Revisiting the trade-offs and policy options. Social Protection Discussion Paper, Series no. SP 0314. The World Bank, Washington, DC.

Sayeed, A. (2004). Social protection in Pakistan: Concept, situation analysis and the way forward. Working Paper 5, Islamabad: Center for Research on Poverty Reduction and Income Distribution.

Selden, T. M., \&Wasylenko, M. J. (1992). Benefit incidence analysis in developing countries. Country Economic Department, Working Paper No. 1015, The World Bank.

Slater, R., \& Farrington, J. (2009). Targeting of social transfers: A review for DFID. Overseas Development Institute (ODI), London. Retrieved from http://www.odi.org.uk/resources/download/4521.pdf

Subbarao, K., A., Bonnerjee, J., Braithwaite, S., Carvalho, K., Ezemenari, C., \& Thompson, A. (1997). Safety net programs and poverty reduction: lessons from cross-country experience (English). Directions in development, Washington, D.C.: The World Bank. Retrieved from http://documents. worldbank.org/curated/en/666481468781474860/Safety-net-programs-and-poverty-reduction-lessons-from-cross-country-experience 
World Bank, (2002). Pakistan - Poverty assessment: Poverty in Pakistan - vulnerabilities, social caps, and rural dynamics (English). Washington, DC: World Bank. 


\section{APPENDIX}

\section{Appendix I: Construction of per capita GDP shock}

The per capita GDP Shock is constructed from the residual series which is obtained from the standard growth regression. This proxy is useful to know as to how far a province is, from its long-run viable growth level. This standard growth regression is taken from the growth literature by simply regressing the log GDP on initial GDP, population growth, and capital per worker.

$$
\operatorname{Logpcgdp}{ }_{\mathrm{it}}=\operatorname{pcgdp}_{\mathrm{it}}+\operatorname{popg}_{\mathrm{it}}+\mathrm{cpw}_{\mathrm{it}}+\vartheta_{\mathrm{it}}
$$

where,

$\operatorname{Logpcgdp}_{\mathrm{it}}=\quad$ Log of per capita gross domestic product for province i at time t;

$\operatorname{pcgdp}_{\mathrm{it}} \quad=\quad$ Initial per capita gross domestic product for province $\mathrm{i}$ at time t;

$\begin{array}{lll}\operatorname{popg}_{\mathrm{it}} & =\quad \text { Population growth for province } \mathrm{i} \text { at time } \mathrm{t} ; \\ \mathrm{cpw}_{\mathrm{it}} & =\quad \text { Capital per worker for province } \mathrm{i} \text { at time } \mathrm{t} ;\end{array}$

The residual series is obtained from equation (A-1); taken as the per capita GDP shock variable in the rank and regression analysis.

Appendix II: Results by using the social protection proxies as a percentage of government total expenditures.

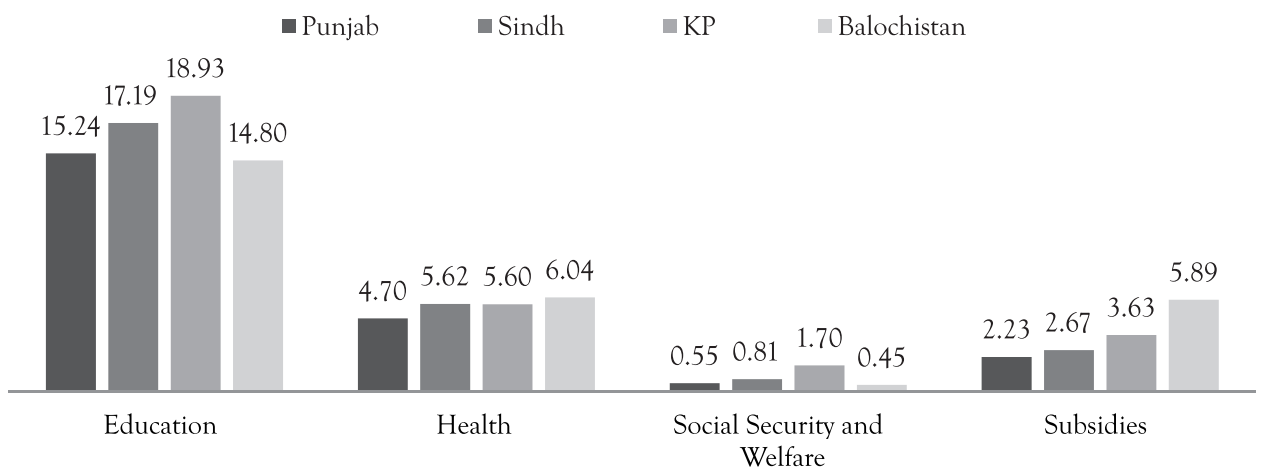

Figure 1-A: Social Protection Expenditures \% of Total Government Expenditures 
Table 2-A: Rank Analysis in context of Social Protection Provision

\begin{tabular}{|c|c|c|c|}
\hline Edu_Exp & Rank-1 & Rank-2 & Rank-3 \\
\hline KP & 1 & 1 & 2 \\
\hline Sindh & 2 & 2 & 1 \\
\hline Punjab & 3 & 3 & 3 \\
\hline Balochistan & 4 & 4 & 4 \\
\hline
\end{tabular}

\begin{tabular}{|c|c|c|c|}
\hline Health_Exp & Rank-1 & Rank-2 & Rank-3 \\
\hline Balochistan & 1 & 4 & 4 \\
\hline Sindh & 2 & 3 & 3 \\
\hline KP & 3 & 1 & 1 \\
\hline Punjab & 4 & 2 & 2 \\
\hline
\end{tabular}

\begin{tabular}{|c|c|c|c|}
\hline Social S\&Welf. & Rank-1 & Rank-2 & Rank-3 \\
\hline KP & 1 & 4 & 2 \\
\hline Sindh & 2 & 3 & 4 \\
\hline Punjab & 3 & 2 & 3 \\
\hline Balochistan & 4 & 1 & 1 \\
\hline
\end{tabular}

\begin{tabular}{|c|c|c|c|}
\hline Sub \& Trasf & Rank-1 & Rank-2 & Rank-3 \\
\hline Balochistan & 1 & 1 & 3 \\
\hline KP & 2 & 2 & 2 \\
\hline Sindh & 3 & 3 & 1 \\
\hline Punjab & 4 & 4 & 4 \\
\hline
\end{tabular}

Author's Calculations

Table 3-A: Regression Analysis for Structural Features and Social Protection

\begin{tabular}{|c|c|c|c|c|}
\hline $\begin{array}{l}\text { Dependent } \\
\text { Variable }\end{array}$ & Edu_Exp & Health_Exp & Social S \&Welf & Sub \& Trasf \\
\hline Variable & $\begin{array}{l}\text { Coefficient } \\
\text { (t-Statistic) }\end{array}$ & $\begin{array}{l}\text { Coefficient } \\
\text { (t-Statistic) }\end{array}$ & $\begin{array}{l}\text { Coefficient } \\
\text { (t-Statistic) }\end{array}$ & $\begin{array}{l}\text { Coefficient } \\
\text { (t-Statistic) }\end{array}$ \\
\hline \multirow[t]{2}{*}{ C } & 3.010 & 0.354 & -0.411 & 0.818 \\
\hline & $(4.728)^{*}$ & $(2.437)$ * & $(-3.352) *$ & $(4.439)$ * \\
\hline \multirow[t]{2}{*}{ LPCGDP } & -0.803 & -0.077 & 0.129 & -0.223 \\
\hline & $(-4.283) *$ & $(-1.808)^{* *}$ & $(3.575)$ * & $(-4.135)^{*}$ \\
\hline \multirow[t]{2}{*}{ WAPOP } & -0.345 & -0.151 & -0.089 & 0.392 \\
\hline & $(-1.625)$ & $(-3.116)^{*}$ & $(-2.171)^{*}$ & $(1.857)^{* *}$ \\
\hline \multirow[t]{2}{*}{ GDPSHOCK } & 0.260 & 0.016 & 0.034 & -0.039 \\
\hline & $(4.762) *$ & $(1.263)$ & $(3.251) *$ & $(-2.669) *$ \\
\hline \multirow[t]{2}{*}{ URBPOP } & 0.006 & 0.002 & -0.001 & 0.001 \\
\hline & $(3.751)^{*}$ & $(2.109) *$ & $(-3.052) *$ & $(2.319)$ * \\
\hline R-squared & 0.282 & 0.129 & 0.198 & 0.304 \\
\hline $\begin{array}{l}\text { Adjusted } \\
\text { R-squared }\end{array}$ & 0.254 & 0.095 & 0.167 & 0.276 \\
\hline F-statistic & 10.111 & 3.811 & 6.358 & 10.814 \\
\hline Prob(F-statistic) & $(0.000)^{*}$ & $(0.006)^{*}$ & $(0.000)^{*}$ & $(0.000)^{*}$ \\
\hline
\end{tabular}

Source: Author's estimation, Note: Social Security and Welfare (SSEC), Subsidies and Transfers (SUB), * and ** significant value at $5 \%$ and $10 \%$ level of significance. 
Table 4-A: Regression Analysis for Institutional FeaturesandSocialProtection

\begin{tabular}{|c|c|c|c|c|}
\hline $\begin{array}{l}\text { Dependent } \\
\text { Variable }\end{array}$ & Edu_Exp_R & Health_Exp_R & $\begin{array}{c}\text { Social S } \\
\text { \&Welf_R }\end{array}$ & Sub \&Trasf_R \\
\hline Variable & $\begin{array}{l}\text { Coefficient } \\
\text { (t-Statistic) }\end{array}$ & $\begin{array}{l}\text { Coefficient } \\
\text { (t-Statistic) }\end{array}$ & $\begin{array}{l}\text { Coefficient } \\
\text { (t-Statistic) }\end{array}$ & $\begin{array}{l}\text { Coefficient } \\
\text { (t-Statistic) }\end{array}$ \\
\hline \multirow[t]{2}{*}{$\mathrm{C}$} & 0.035 & -0.003 & -0.009 & 0.024 \\
\hline & $(0.915)$ & $(-0.413)$ & $(-1.087)$ & $(2.224)^{*}$ \\
\hline \multirow[t]{2}{*}{ VTO } & 0.001 & 0.001 & 0.001 & -0.002 \\
\hline & $(0.473)$ & $(0.399)$ & $(0.647)$ & $(-2.542)^{*}$ \\
\hline \multirow[t]{2}{*}{ LR } & -0.002 & -0.002 & 0.002 & 0.001 \\
\hline & $(-1.793)^{* *}$ & $(-0.555)$ & $(0.293)$ & $(0.932)$ \\
\hline \multirow[t]{2}{*}{ DSSP } & -0.023 & -0.005 & -0.071 & -0.125 \\
\hline & $(-0.029)$ & $(-0.026)$ & $(-0.429)$ & $(-0.569)$ \\
\hline \multirow[t]{2}{*}{ POLITY } & 0.005 & 0.002 & 0.001 & -0.001 \\
\hline & $(3.507)^{*}$ & $(4.336)^{*}$ & $(0.356)$ & $(2.356)^{*}$ \\
\hline R-squared & 0.174 & 0.189 & 0.016 & 0.134 \\
\hline $\begin{array}{l}\text { Adjusted } \\
\text { R-squared }\end{array}$ & 0.139 & 0.155 & -0.024 & 0.098 \\
\hline F-statistic & 5.148 & 5.692 & 0.397 & 3.777 \\
\hline Prob(F-statistic) & $(0.001)^{*}$ & $(0.000)^{*}$ & $(0.811)$ & $(0.006)^{*}$ \\
\hline
\end{tabular}

Source: Author's estimation, Note: (_R) residual series get from the system of equations (4), *and ** significant value at $5 \%$ and $10 \%$ level of significance respectively. 
